DOI:10.22337/2587-9618-2019-15-4-25-33

\title{
STABILITY OF THREE-LAYER RODS WITH ALLOWANCE FOR INITIAL IMPERFECTIONS AND SHEAR DEFORMATIONS
}

\author{
Viacheslav S. Chepurnenko, Batyr M. Yazyev \\ Don State Technical University, Rostov-on-Don, Russia
}

\begin{abstract}
The article presents the derivation of equations describing the pre-buckling behavior of three-layer rods in the presence of shear deformation and creep of the middle layer. The test problem for a rod with a filler made of polyurethane foam is solved. A technique has been developed for calculating the critical time under loads which values exceed the long critical ones.
\end{abstract}

Keywords: three-layer beams, stability, shear, creep, numerical methods

\section{УСТОЙЧИВОСТЬ ТРЕХСЛОЙНЫХ СТЕРЖНЕЙ ПРИ ПОЛЗУЧЕСТИ С УЧЕТОМ НАЧАЛЬНЫХ НЕСОВЕРШЕНСТВ И ДЕФОРМАЦИЙ СДВИГА}

\author{
В.С. Чепурненко, Б.М. Языев \\ Донской государственный технический университет, г. Ростов-на-Дону, РОССИЯ
}

\begin{abstract}
Аннотация: В статье приводится вывод уравнений, описывающих докритическое поведение трёхслойных стержней при наличии сдвиговых деформаций и ползучести среднего слоя. Решается тестовая задача для стержня с заполнителем из пенополиуретана. Разработана методика вычисления критического времени при нагрузках, значения которых превышают длительные критические.
\end{abstract}

Ключевые слова: трехслойные балки, устойчивость, сдвиг, ползучесть, численные методы

\section{INTRODUCTION}

When solving the problems of stability of rods, in many cases it is necessary to take into account shear deformations: for example, when considering elements made of anisotropic fibrous materials with a shear modulus significantly smaller than the elastic modulus or when calculating three-layer rods consisting of two thin metal outer layers and a lightweight, much less rigid filler. Taking into account the shear force in deformable elements of this type leads to obtaining lower critical loads than without taking it into account. There is a formula in [1] derived analytically to calculate the critical force, acting on central-compressed three-layer rod. It is important to note that the polymer filler is subjected to creep, accordingly, the actual values of the loads leading to buckling will be lower than those obtained in the book [1], which should be taken into account in the calculations and structural analysis.

\section{DERIVATION OF RESOLVING EQUATIONS}

We consider the element shown in Figure 1, subject to longitudinal bending. In deriving the equations, we take the Timoshenko's model as a model of rod deformation, which includes shear deformations in the calculations.

In Figure 1 the following notation is accepted: $\gamma_{x z}$-shear strain (it is equal to the angle between the plane, normal to the median surface and the cross section plane), $\varphi$ - the angle of cross section rotation relative to the initial position, 


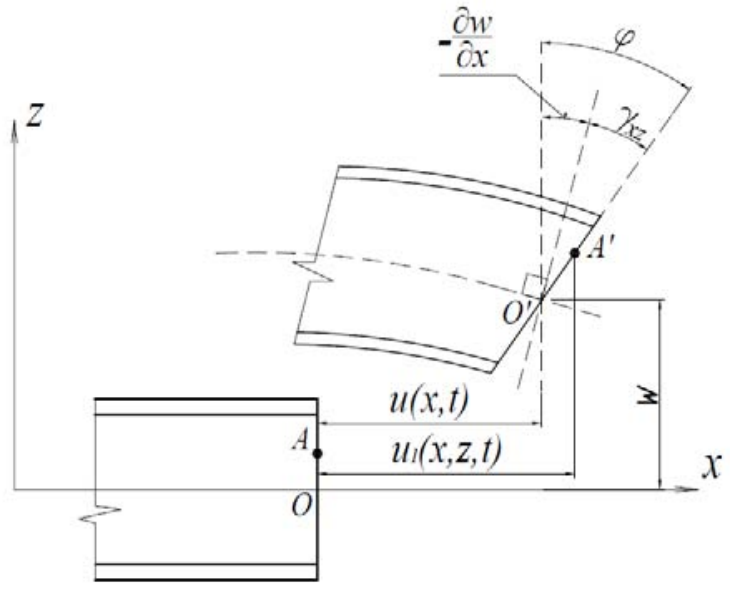

Figure 1. Element of rod subject to longitudinal bending.

$u_{1}(x, z, t)$ - the displacement of a certain point $A$ of the cross section in the $x$ direction.

As follows from Figure 1:

$$
\begin{aligned}
\gamma_{x z} & =\varphi+\frac{\partial w}{\partial x}, \\
u_{1}(x, z, t) & =u(x, t)+z \varphi(x, t) .
\end{aligned}
$$

We take into account the initial imperfection, defined by some function $w_{0}(x)$, according to the method, mentioned in [2], assuming that the displacements of the points along the $\mathrm{z}$ axis are:

$$
u_{3}=w_{0}(x)+w(x, t),
$$

and then eliminating from the terms of the Green strain tensor components those, that contain only $w_{0}(x)$, since they correspond only to the initial imperfections, when the stresses in the rod are equal to zero. Neglecting the terms of large order of smallness, we thus obtain:

$$
\begin{gathered}
\varepsilon_{11}=\varepsilon_{x x}=\frac{\partial u_{1}}{\partial x_{1}}+\frac{1}{2}\left(\frac{\partial u_{3}}{\partial x_{1}}\right)^{2}=\frac{\partial u}{\partial x}+z \frac{\partial \varphi}{\partial x}+ \\
+\frac{1}{2}\left(\frac{\partial w}{\partial x}\right)^{2}+\frac{\partial w}{\partial x} \frac{\partial w_{0}}{\partial x} \\
\varepsilon_{x y}=\varepsilon_{x z}=\varepsilon_{y z}=\varepsilon_{z z}=\varepsilon_{y y}=0
\end{gathered}
$$

According to the generalized Hooke's law for the isotropic material of filler with creep strain taken into account:

$$
\left\{\begin{array}{l}
\varepsilon_{x x}=\varepsilon_{x x}^{e l}+\varepsilon_{x x}^{*}=\frac{1}{E_{f}} \sigma_{x x}+\varepsilon_{x x}^{*} \\
\gamma_{x z}=\gamma_{x z}^{e l}+\gamma_{x z}^{*}=\frac{1}{G_{f}} \sigma_{x z}+\gamma_{x z}^{*}
\end{array},\right.
$$

the symbol «*» indicates creep strain, $\varepsilon_{x x}^{e l}, \gamma_{x z}^{e l}$ elastic strains, $E_{f}, G_{f}$ - filler characteristics.

We write the expression of the variational principle of the minimum total potential energy [3]:

$$
\Pi=\delta(U+V)=\delta U+\delta V=0,
$$

$U$ - potential elastic strain energy, $V$ - external forces potential;

$$
\begin{aligned}
& \delta U=\int_{V}\left(\sigma_{x x} \delta \varepsilon_{x x}^{e l}+\sigma_{x z} \delta \gamma_{x z}^{e l}\right) d V= \\
& =\int_{V}\left(\sigma_{x x} \delta\left(\varepsilon_{x x}-\varepsilon_{x x}^{*}\right)+\sigma_{x z} \delta\left(\gamma_{x z}-\gamma_{x z}^{*}\right)\right) d V=(8) \\
& =\int_{L} \int_{A}\left(\sigma_{x x} \delta \varepsilon_{x x}+\sigma_{x z} \delta \gamma_{x z}\right) d A d x .
\end{aligned}
$$

In equation (8) the variations of creep strains are equal to zero, as is in subsequent numerical calculation step method at a small interval of time $\Delta t$ the creep strains will depend only on the components of the stress tensor, obtained in the points of the rod in the previous step.

In the case of joint support of the rod (Figure 2), compressed by the force $P$, with one movable joint in the $\mathrm{x}$ direction and one stationary joint, the variation of the external forces potential will be equal to:

$$
\delta V=-P \delta u(x=0) .
$$




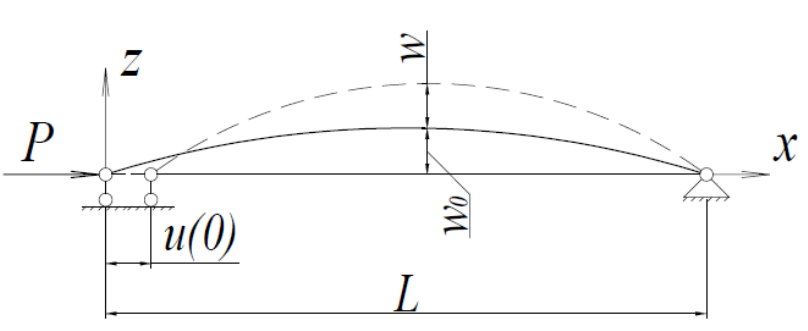

Figure 2. Loading model.

We denote the axial, shear forces and bending moment as:

$$
N_{x}=\int_{A} \sigma_{x x} d A, Q=\int_{A} \sigma_{x z} d A, M=\int_{A} \sigma_{x x} z d A
$$

Substituting in (8) and varying the components of the strains given in (1), (4), we obtain the expression:

$$
\begin{aligned}
& \delta U=\int_{L}\left(N_{x}\left(\frac{\partial \delta u}{\partial x}+\frac{\partial \delta w}{\partial x} \frac{\partial w}{\partial x}+\frac{\partial \delta w}{\partial x} \frac{\partial w_{0}}{\partial x}\right)+\right. \\
& \left.+M \frac{\partial \delta \varphi}{\partial x}+Q\left(\delta \varphi+\frac{\partial \delta w}{\partial x}\right)\right) d x
\end{aligned}
$$

Applying integration by parts and grouping the terms with factors $\delta u, \delta w, \delta \gamma_{x z}$ in expression (11) and substituting it together with (9) in (7), we get the following result:

$$
\begin{aligned}
& N_{x}(L) \delta u(L)-\left(N_{x}(0) \delta u(0)+P \delta u(0)\right)+ \\
& +\left.\left(N_{x} \frac{\partial w_{0}}{\partial x}+N_{x} \frac{\partial w}{\partial x}+Q\right) \delta w\right|_{0} ^{L}+\left.M \delta \varphi\right|_{0} ^{L}+ \\
& +\int_{L}\left(\left(-\frac{\partial N_{x}}{\partial x}\right) \delta u+\left(-\frac{\partial}{\partial x}\left(N_{x}\left(\frac{\partial w}{\partial x}+\frac{\partial w_{0}}{\partial x}\right)\right)-\right.\right. \\
& \left.\left.-\frac{\partial Q}{\partial x}\right) \delta w+\left(-\frac{\partial M}{\partial x}+Q\right) \delta \varphi\right) d x=0 .
\end{aligned}
$$

In accordance with the main lemma of the variational calculus, we obtain the system:

$$
\left\{\begin{array}{l}
-\frac{\partial N_{x}}{\partial x}=0 \\
-\frac{\partial}{\partial x}\left(N_{x}\left(\frac{\partial w}{\partial x}+\frac{\partial w_{0}}{\partial x}\right)\right)-\frac{\partial Q}{\partial x}=0, x \in(0 ; L) \\
-\frac{\partial M}{\partial x}+Q=0
\end{array}\right.
$$

From the fixing conditions for the rod we have:

$$
\begin{aligned}
& w(0, t)=w(L, t)=u(L, t)=0=>\delta w(0, t)= \\
& =\delta w(L, t)=\delta u(L, t)=0
\end{aligned}
$$

at an arbitrary point of time. For convenience, we omit the time $t$ during subsequent writing in the notation of time-dependent functions. We get the final set of six boundary conditions:

$$
\left\{\begin{array}{l}
w(0)=w(L)=u(L)=0 \\
N_{x}(0)+P=0 \\
M(0)=M(L)=0
\end{array},\right.
$$

Using dependencies (13), (15), we transform (13) to a system of two differential equations:

$$
\left\{\begin{array}{l}
P\left(\frac{\partial^{2} w}{\partial x^{2}}+\frac{\partial^{2} w_{0}}{\partial x^{2}}\right)=\frac{\partial Q}{\partial x} \\
Q=\frac{\partial M}{\partial x}
\end{array}\right.
$$

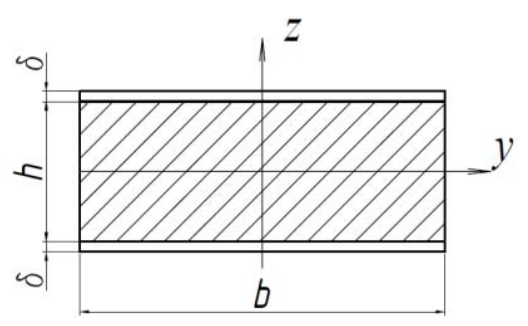

Figure 3. Rod cross section.

We substitute the formulas for strains and Hooke's law (6) in expressions (10) for the stresses, taking into account the cross sectional parameters with the dimensions shown in Fig. 3. We obtain: 


$$
\begin{aligned}
& M=\int_{A} E(z)\left(\frac{\partial u}{\partial x}+z \frac{\partial \varphi}{\partial x}+\frac{1}{2}\left(\frac{\partial w}{\partial x}\right)^{2}+\right. \\
& \left.+\frac{\partial w}{\partial x} \frac{\partial w_{0}}{\partial x}-\varepsilon_{x x}^{*}\right) z d A=\int_{A} E\left(z^{2} \frac{\partial \varphi}{\partial x}-\varepsilon_{x x}^{*} z\right) d A= \\
& =\left(E_{s} I_{s}+E_{f} I_{f}\right) \frac{\partial \varphi}{\partial x}-E_{f} \int_{A_{f}} \varepsilon_{x x}^{*} z d A
\end{aligned}
$$

$E_{s}$-modulus of elasticity of the metal sheathings, $I_{s}, I_{f}-$ moments of inertia of the metal and polymer cross section parts,

$$
\begin{gathered}
I_{s} \approx\left(h \delta^{2}+\frac{\delta h^{2}}{2}\right) b, \quad I_{f}=\frac{b h^{3}}{12} . \\
Q=\int_{A_{f}} \sigma_{x z} d A=\int_{A_{f}} G_{f}\left(\gamma_{x z}-\gamma_{x z}^{*}\right) d A= \\
=K_{s} G_{f} \gamma_{x z} A_{f}-G_{f} \int_{A_{f}} \gamma_{x z}^{*} d A .
\end{gathered}
$$

Integration in expression (19) is performed over the filler area due to the insignificant thickness of metal plates that work only on compression, $K_{s}$ is a coefficient that takes into account the irregular distribution of shear stresses over the section height (It is assumed in the Timoshenko model that $\gamma_{x z}$ is constant in height). According to [4], the coefficient value for a rectangular section takes the form:

$$
K_{s}=\frac{10\left(1+v_{f}\right)}{12+11 v_{f}} .
$$

For convenience, we introduce the notation for integrals containing components of creep strains:

$$
M^{*}=E_{f} \int_{A_{f}} \varepsilon_{x x}^{*} z d A, Q^{*}=G_{f} \int_{A_{f}} \gamma_{x z}^{*} d A,
$$

We substitute (17), (19) into (16), taking into account the previously introduced notation:

$$
\left\{\begin{array}{l}
P\left(\frac{\partial^{2} w}{\partial x^{2}}+\frac{\partial^{2} w_{0}}{\partial x^{2}}\right)=K_{s} G_{f} A_{f}\left(\frac{\partial \varphi}{\partial x}+\frac{\partial^{2} w}{\partial x^{2}}\right)-\frac{\partial Q^{*}}{\partial x} \\
K_{s} G_{f} A_{f}\left(\varphi+\frac{\partial w}{\partial x}\right)-Q^{*}= \\
=\left(E_{s} I_{s}+E_{f} I_{f}\right) \frac{\partial^{2} \varphi}{\partial x^{2}}-\frac{\partial M^{*}}{\partial x}
\end{array}\right.
$$

Transferring all terms with $w$ and $\varphi$ to the left side of the system and dividing by $K_{s} G_{f} A_{f}$, we obtain the final system of resolving partial differential equations (21):

$$
\left\{\begin{array}{l}
\frac{\partial^{2} w}{\partial x^{2}}\left(1-\frac{P}{K_{s} G_{f} A_{f}}\right)+\frac{\partial \varphi}{\partial x}=\frac{P}{K_{s} G_{f} A_{f}} \frac{\partial^{2} w_{0}}{\partial x^{2}}+ \\
+\frac{1}{K_{s} G_{f} A_{f}} \frac{\partial Q^{*}}{\partial x} \\
\frac{\partial w}{\partial x}+\varphi-\frac{E_{s} I_{s}+E_{f} I_{f}}{K_{s} G_{f} A_{f}} \frac{\partial^{2} \varphi}{\partial x^{2}}=-\frac{1}{K_{s} G_{f} A_{f}} \frac{\partial M^{*}}{\partial x}
\end{array}\right.
$$

with boundary conditions (22):

$$
\left\{\begin{array}{l}
w(0)=0 \\
w(L)=0 \\
\left(E_{s} I_{s}+E_{f} I_{f}\right) \frac{\partial \varphi}{\partial x}(0)=M^{*}(0) \\
\left(E_{s} I_{s}+E_{f} I_{f}\right) \frac{\partial \varphi}{\partial x}(L)=M^{*}(L)
\end{array}\right.
$$

As a law describing the creep process of a polymer filler, we accept the Maxwell-Gurevich equation [5]:

$$
\frac{\partial \varepsilon_{i j}^{*}}{\partial t}=\left(\frac{3}{2}\left(\sigma_{i j}-p \delta_{i j}\right)-E_{\infty} \varepsilon_{i j}^{*}\right) \frac{1}{\eta^{*}}=\frac{f_{i j}}{\eta^{*}},
$$

$\eta^{*}-$ invariant relaxation viscosity coefficient, $p=\frac{\sigma_{x x}}{3}, \delta_{i j}-$ Kronecker delta, $E_{\infty}-$ modulus of viscoelasticity. 


$$
\eta^{*}=\eta_{0}^{*} \exp \left(-\frac{1}{m^{*}}\left(\left|\frac{3}{2}\left(\sigma_{r r}-p\right)-E_{\infty} \varepsilon_{r r}^{*}\right|_{\max }\right)\right)
$$

the index $r$ denotes the principle directions for stresses, $\eta_{0}^{*}-$ initial relaxation viscosity, $m^{*}-$ velocity module.

\section{METHOD OF CALCULATION}

The system (21) of nonlinear differential equations will be solved by the finite difference method. Formulas for partial derivatives with respect to $x$ used in solving with accuracy $O\left(\Delta x^{2}\right)$ for $i$-th point [6]:

$$
\begin{gathered}
\frac{\partial f\left(x_{i}\right)}{\partial x} \approx \frac{f\left(x_{i+1}\right)-f\left(x_{i-1}\right)}{2 \Delta x}, \\
\frac{\partial^{2} f\left(x_{i}\right)}{\partial x^{2}} \approx \frac{f\left(x_{i-1}\right)-2 f\left(x_{i}\right)+f\left(x_{i+1}\right)}{\Delta x^{2}},
\end{gathered}
$$

here $\Delta x-$ is the distance between adjacent points of the FDM grid.

The system of differential equations (21) with boundary conditions (22) is transformed to a system of linear equations for each time moment $t$. In calculating the creep strain components (23) at different time moments, the Euler's method [7] is used.

We write the system in the form:

$$
\begin{gathered}
{[A]\{X\}=\{B\},} \\
{[A]=\left[\begin{array}{cccc}
a_{1,1} & a_{1,2} & \cdots & a_{1,2 n} \\
a_{2,1} & a_{2,2} & \cdots & a_{2,2 n} \\
\vdots & \vdots & \ddots & \vdots \\
a_{2 n, 1} & \cdots & \cdots & a_{2 n, 2 n}
\end{array} \mid-\right.}
\end{gathered}
$$

matrix containing elements that are constant in time with $2 n \times 2 n$ dimensions.

$\{X\}=\left[\begin{array}{lllllll}w_{1} & \varphi_{1} & w_{2} & \varphi_{2} & \ldots & w_{n} & \varphi_{n}\end{array}\right]^{T}-$ column vector of unknown displacements, $n$ - number of nodes of the FDM grid, including 2 fictitious ones that go on $\Delta x$ beyond the length of the rod $L$ and are used to write expressions for partial derivatives with respect to $x$ at the points of the rod with coordinates $x=0, x=L$.

$\{\mathrm{B}\}=\left[\begin{array}{llll}b_{1} & b_{2} & \cdots & b_{2 n}\end{array}\right]^{T}-$ column vector of free terms with $2 n \times 1$ dimensions.

\section{RESULTS AND DISCUSSION}

When solving a test problem, we use the following data:

rod axis is initially curved according to the equation

$$
\begin{gathered}
w_{0}=f \cdot \sin \left(\frac{\pi x}{L}\right), L=3 \mathrm{~m}, b=0.15 \mathrm{~m}, \\
h=0.05 \mathrm{~m}, \delta=1 \mathrm{~mm},
\end{gathered}
$$

sheathings material is aluminum with $E_{s}=0.7 \cdot 10^{5} \mathrm{MPa}$, the filler material is polyurethane foam with the following characteristics:

$$
\begin{gathered}
G_{f}=5 \mathrm{MPa}, v_{f}=0.3, E_{\infty}=27.38 \mathrm{MPa}, \\
m^{*}=0.0218 \mathrm{MPa}, \eta_{0}^{*}=1.43 \cdot 10^{4} \mathrm{MPa} \cdot \mathrm{h} .
\end{gathered}
$$

According to [1], the critical force for a rod without taking into account the rheological characteristics of the filler material is:

$$
P_{c r}=\frac{P_{c r}^{0}}{1+\frac{P_{c r}^{0}}{G_{f} A_{f}}}=10.71 \mathrm{kN} \text {, }
$$

where $P_{c r}^{0}=\frac{\pi^{2}\left(E_{s} I_{s}+E_{f} I_{f}\right)}{L^{2}}=15 \mathrm{kN}$

- Euler critical force (excluding shear deformations). When a coefficient $K_{s}$ is added to formula (28), the value of the critical force will be equal to: 


$$
P_{c r}=\frac{P_{c r}^{0}}{1+\frac{P_{c r}^{0}}{K_{s} G_{f} A_{f}}}=10.195 \mathrm{kN} .
$$

When calculating the stability of the rod without taking into account the effect of viscoelasticity by the finite element method, a critical load $P_{c r}=10.49 \mathrm{kN}$ was obtained in the LIRASAPR software, the form of stability loss is shown in Figure 4

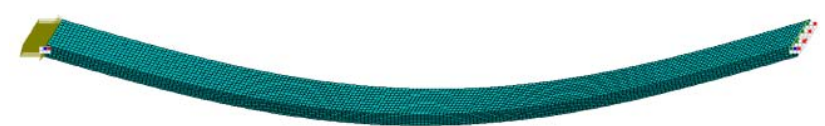

Figure 4. The first form of buckling.

The number of three-dimensional (3D) solid elements when modeling along the height of the filler section is 8 , along the length is 100 . From the ends, the axial load is transferred to the section using the installed additional aluminum plate. From the modeling by $3 \mathrm{D}$ and plate elements in the software package it follows that local loss of stability in thin metal sheathings does not occur.

Next, we perform the calculation taking into account creep effect in accordance with the procedure described in this article using the MATLAB software package.

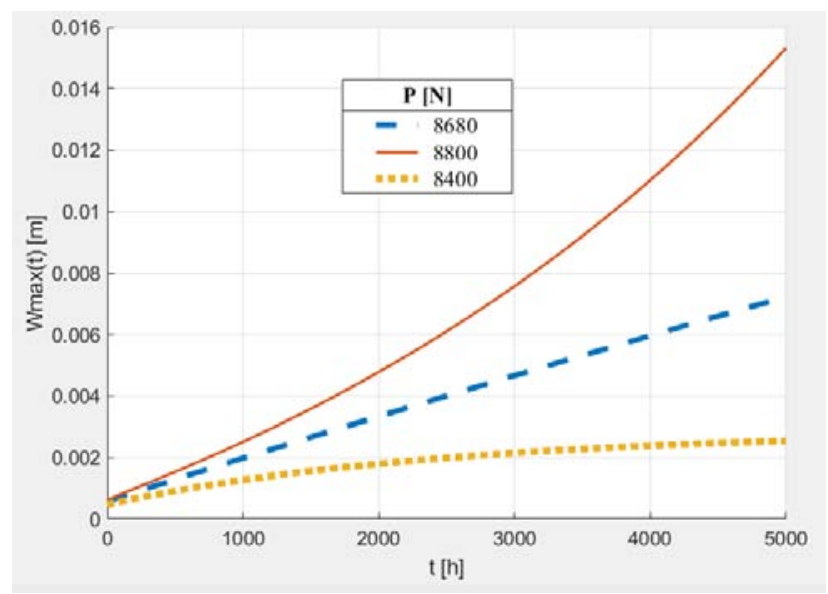

Figure 5. Displacements along z axis versus time for various loads.
In the calculation, the initial deflection parameter was taken to be equal to $f=0.1 \mathrm{~mm}$, number of sectors between nodes along the length of the rod -50 , the number of time steps - 100. An increase in the number of accepted steps and sections leads to negligible changes in the results, the solutions are stable.

In $[8,9]$, when analyzing the stability of viscoelastic rods and beams using the MaxwellGurevich equation, the value of the long-term critical load is introduced by replacing the instantaneous elastic constants $\mathrm{E}$ and $\mathrm{G}$ of the filler by long ones determined by the formulas:

$$
\begin{gathered}
G_{f, l}=\frac{G_{\infty} G_{f}}{G_{\infty}+G_{f}}, \\
E_{f, l}=\frac{E_{\infty} E_{f}}{E_{\infty}+E_{f}},
\end{gathered}
$$

here $G_{\infty}=\frac{E_{\infty}}{3}$, the long-term Poisson's ratio of the material used in calculating the coefficient $K_{s}[10]$ :

$$
v_{f, l}=\frac{\alpha^{*}}{\beta^{*}}
$$

where $\alpha^{*}=\frac{1}{E_{f}}+\frac{1}{E_{\infty}}, \beta^{*}=\frac{v_{f}}{E_{f}}+\frac{1}{2 E_{\infty}}$.

Using this technique, we write down the longterm critical force in the form:

$$
P_{l}=\frac{P_{l}^{0}}{1+\frac{P_{l}^{0}}{K_{s, l} G_{f, l} A_{f}}}=8.683 \mathrm{kN},
$$

where $P_{l}^{0}=\frac{\pi^{2}\left(E_{s} I_{s}+E_{f, l} I_{f}\right)}{L^{2}}$.

As can be seen from the graphs shown in Figure 5 when $P_{l} \approx 8680 \mathrm{~N}$ the creep process is steady, 
the deflection grows at a constant speed. This result with a high degree of accuracy corresponds to the value obtained in expression (33). At loads lower than $P_{l}$, the deflection growth gradually slows down, at loads $P>P_{l}$ the deflection growth accelerates. Note that the nature of the curves does not change for various parameters of the initial imperfections $f$, which affect only the final value of the deflection during decreasing creep, as well as the critical time during buckling. We demonstrate this in Fig. 6, showing the influence of the parameter of initial imperfections $f$ on the critical time at a load $P=8900 \mathrm{~N}>P_{l}$. In the general case, the initial imperfections of real structures are arbitrary and have a wide range of values, due to both technological and operational reasons, respectively, the actual values of long-term loads under which the presented structure works must be less than $P_{l}$.

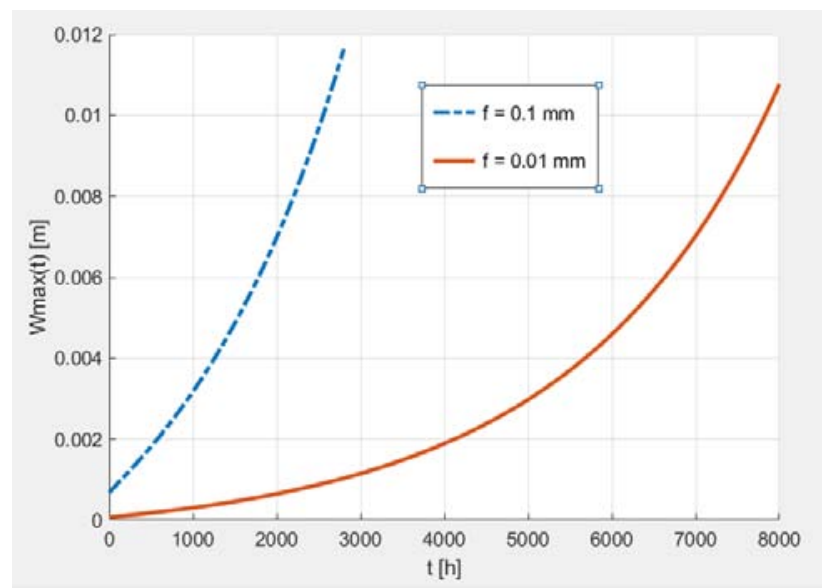

Figure 6. The influence of the initial imperfection on the critical time, $P=8900 \mathrm{~N}$.

Thus, in the presence of complete data on the characteristics of the materials and the initial imperfections, it seems possible to calculate the critical time.

In order to simplify the solution, normal stresses in the filler can be neglected if its elastic modulus is low, assuming that all normal stress is perceived by metal sheathings. The effect of taking into account normal stresses in the filler on the critical time is shown in Figure 7.

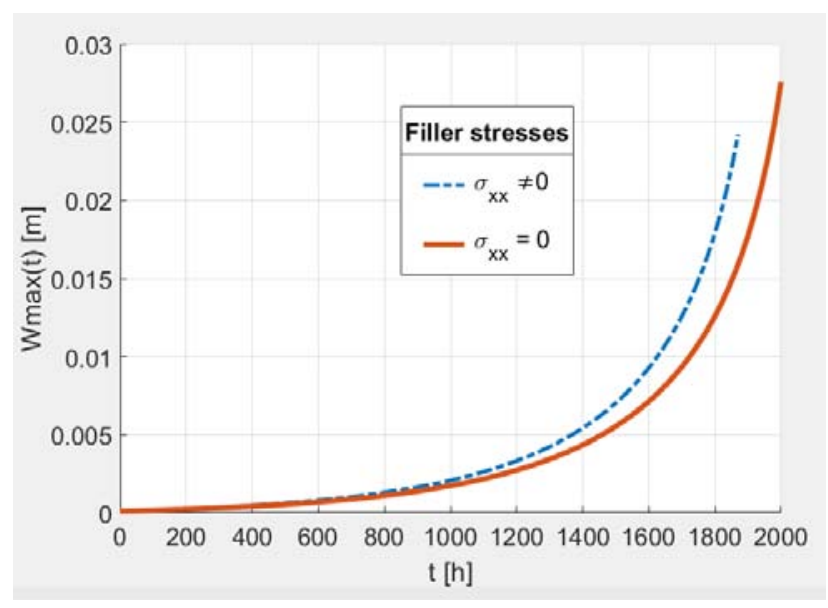

Figure 7. The effect of taking into account normal stresses in the filler on the critical time, $P=9400 \mathrm{~N}$.

Obviously, when using a polymer filler with greater rigidity, the difference between the critical time obtained without taking into account the normal stresses in it and taking them into account will increase significantly.

\section{CONCLUSIONS}

In the article, resolving equations are obtained that describe the process of rod buckling taking into account shear deformations and creep effects, and a method for numerically solving them is given. The presented algorithm for solving the problem allows us to determine the critical load leading to loss of stability, the critical time in the presence of data on the initial imperfections of the compressed structure, and also to trace the history of its deformation in time. The test problem is solved under various loads.

For the initial data corresponding to part 3 of this article, the difference in critical loads when taking into account creep and without considering it is equal to:

$$
\frac{10.2-8.68}{10.2} \cdot 100 \%=14.9 \%,
$$


which is important to consider when designing such three-layer elements in schemes that allow their work under compression forces.

\section{REFERENCES}

1. Alfutov N.A. Osnovy raschyota na ustojchivost' uprugih sistem [Basics of calculating the stability of elastic systems]. Moscow, Mashinostroyenie, 1978, 312 pages (in Russian).

2. Amabili M. Nonlinear mechanics of shells and plates in composite, soft and biological materials. New York, Cambridge University Press, 2018, 568 pages.

3. Reddy J.N. Energy principles and variational methods in applied mechanics. 2nd Edition. New York, John Wiley, 2002, 608 pages.

4. Wang, C.M., Wang, C.Y., Reddy, J.N. Exact solutions for buckling of structural members. Florida, CRC Press LLC, 2004, 224 pages.

5. Goldman A.Y. Prochnost' konstrukcionnyh plastmass [Strength of structural plastics]. Leningrad, Mashinostroyenie, 1979, 320 pages (in Russian).

6. Esfandiari R.S. Numerical methods for engineers and scientists using MATLAB. 2nd edition. Florida, CRC Press LLC, 2017, 417 pages.

7. Yazyev B.M., Chepurnenko A.S., Litvinov S.V., Kozel'skaya M.Yu. Napryazhenno-deformirovannoe sostoyanie predvaritel'no napryazhennogo zhelezobetonnogo tsilindra $\mathrm{s}$ uchetom polzuchesti betona [Stress-strain state of a prestressed reinforced concrete cylinder with the consideration of concrete creep] // Nauchnoe obozrenie, 2014, No. 11, part 3, pp. 759-763 (in Russian).

8. Zotov I.M., Chepurnenko A.S., Yazyev S.B. Raschet na ustoychivost' ploskoy formy izgiba balok pryamougol'nogo secheniya $\mathrm{s}$ uchetom polzuchesti [Calculation of the flat bending shape stability of rectangular cross section beams with regard to creep] // Herald of Dagestan State Technical University. Technical Sciences, 2019, Vol. 46(1), pp. 169-176 (in Russian).

9. Nikora N.I., Chepurnenko A.S., Litvinov S.V. Opredelenie dlitelnyh kriticheskih nagruzok dlya szhatyh polimernyh sterzhnej pri nelinejnoj polzuchesti [Determination of long-term critical loads for compressed polymer rods with nonlinear creep] // Inzhenernyj vestnik Dona, 2015, no 1, part 2. URL: ivdon.ru/ru/magazine/archive/n1p2y2015/2 796 (in Russian).

10. Litvinov S.V., Danilova-Volkovskaya G. M., Dudnik A. E., Chepurnenko A. S. Napryazhenno-deformirovannoe sostoyanie mnogosloynykh polimernykh trub $\mathrm{s}$ uchetom polzuchesti materiala [Stress-strain state of multilayer polymer pipes taking into account the creep of material] // Sovremennaya nauka $i$ innovatsii, 2015, no 3 (11), pp. 71-78 (in Russian).

\section{СПИСОК ЛИТЕРАТУРЫ}

1. Алфутов Н.А. Основы расчета на устойчивость упругих систем. - М.: Машиностроение, 1978. - 312 с.

2. Amabili M. Nonlinear mechanics of shells and plates in composite, soft and biological materials. New York, Cambridge University Press, 2018, 568 pages.

3. Reddy J.N. Energy principles and variational methods in applied mechanics. 2nd Edition. New York, John Wiley, 2002, 608 pages.

4. Wang, C.M., Wang, C.Y., Reddy, J.N. Exact solutions for buckling of structural members. Florida, CRC Press LLC, 2004, 224 pages.

5. Гольдман А.Я. Прочность конструкционных пластмасс. - Л.: Машиностроение, 1979. - 320 с. 
6. Esfandiari R.S. Numerical methods for engineers and scientists using MATLAB. 2nd edition. Florida, CRC Press LLC, 2017, 417 pages.

7. Языев Б.М., Чепурненко А.С., Литвинов С.В., Козельская М.Ю. Напряженно-деформированное состояние предварительно напряженного железобетонного цилиндра с учетом ползучести бетона. // Научное обозрение, №11, часть 3, 2014, с. 759-763.

8. Зотов И.М., Чепурненко А.С., Языев C.Б. Расчет на устойчивость плоской формы изгиба балок прямоугольного сечения с учетом ползучести. // Вестник Дагестанского государственного технического университета. Технические науки, №46(1), 2019, с. 169176.

9. Никора Н.И., Чепурненко А.С., Литвинов С.В. Определение длительных критических нагрузок для сжатых полимерных стержней при нелинейной ползучести. // Инженерный вестник Дона, №1, часть 2, 2015.

11. Литвинов С.В., Данилова-Волковская Г.М., Дудник А.Е., Чепурненко А.С. Напряженно-деформированное состояние многослойных полимерных труб с учетом ползучести материала. // Современная науки и инноваџии, №3(11), 2015, c. 71-78 (in Russian).

Языев Батыр Меретович, советник Российской академии архитектуры и строительных наук (РААСН), доктор технических наук, профессор кафедры «Сопротивление материалов» Донского государственного технического университета, 344022 , Россия, Ростов-на-Дону, ул. Социалистическая, 162; тел.: +7(863)201-91-36; e-mail: ps62@yandex.ru; http://orcid.org/0000-0002-5205-1446

Чепурненко Вячеслав Сергеевич, студент Донского государственного технического университета, 344022, Россия, Ростов-на-Дону, ул. Социалистическая, 162; тел.: +7(919)888-09-24;

E-mail: chepurnenkoviacheslav@gmail.com; https://orcid.org/0000-0001-6033-2603.
Yazyev Batyr Meretovich, Advisor of the Russian Academy of Architecture and Construction Sciences (RAACS), Doctor of Technical Sciences, Professor of the Department "Strength of Materials", Don State Technical University, 344022, Russia, Rostov-on-Don, Sotcialisticheskaya st., 162; phone: +7 (863) 201-91-36;

E-mail: ps62@yandex.ru;

https://orcid.org/0000-0002-5205-1446.

Chepurnenko Viacheslav Sergeevich, student, Don State Technical University, 344022, Russia, Rostov-on-Don, Sotcialisticheskaya st., 162; phone: +7(919)888-09-24;

E-mail: chepurnenkoviacheslav@gmail.com; https://orcid.org/0000-0001-6033-2603. 